\title{
An Illuminative Evaluation on Practical Art, Craft and Design Instruction: The Case of Botswana
}

\author{
Dr. Magdeline C. Mannathoko ${ }^{1} \&$ Dr. Thenjiwe E. Major ${ }^{1}$ \\ ${ }^{1}$ University of Botswana, Botswana \\ Correspondence: Dr. Magdeline C. Mannathoko, University of Botswana, Botswana. E-mail: \\ mannathoko@mopipi.ub.bw \\ Received: May 8, 2013 \\ Accepted: July 1, 2013 \\ Online Published: July 17, 2013 \\ doi:10.5430/ijhe.v2n3p54 \\ URL: http://dx.doi.org/10.5430/ijhe.v2n3p54
}

\begin{abstract}
Art, craft and design (ACD) is a practical subject that provides learners the opportunity to explore various media and techniques. This includes creating two and three dimensional work in order to help learners develop their practical skills which may benefit them in future. Learners may create products to sell and earn a living as the National Principles and 'Vision 2016' advocate for 'self-reliance'. Thus, effective engagement of learners in practical activities may help them develop creative and practical skills resulting in benefits in the completion of primary school studies. Engagement in the development of creative and practical skills is particularly helpful for those who do not advance to secondary education. It is in this context, that this study investigated the extent to which primary school teachers engaged pupils in ACD practical activities. The study also examined the application of ACD theory to practice as advocated by the Botswana Lower Primary Creative and Performing Arts syllabus, which was introduced in 2002. This was a qualitative case study which involved eight lower primary teachers. The research methodology was framed within Parlett and Hamilton's concept of 'Illuminative Evaluation' accompanied by classroom participant observation. The study revealed that all of the teachers who participated in the study had limited knowledge and skills in art, craft and design. None of them had specialized in the subject. The results further indicated that teachers had been trained in basic pedagogy on the general methods of teaching in primary schools; however, they lacked knowledge and skills in ACD. This deficit may have contributed to their lack of encouraging learners to apply theory into practice, thus depriving them the opportunity to gain basic practical skills required at primary level.
\end{abstract}

Keywords: Illuminative evaluation, Art craft and design practical activities, Art elements, Guidance, Practical skills, Creativity skills, Self-reliance

\section{Introduction}

In Botswana, art, craft and design has always been part of the people's lives. It was used to communicate their ways of lives. Chanda (1993) noted that, through the ages, art and craft in African countries has integrated and celebrated different aspects of life, politics, religion, personal beliefs and ways of responding to the outside world. In Botswana during the pre-colonial era, art and craft activities were passed from one generation to another, through informal oral and practical education. Girls learned pottery and weaving from their mothers, grandmothers and aunts. Boys learned wood carving from their fathers, grandfathers and uncles to create objects such as stools, wooden spoons, wooden plates. Despite the fact that Batswana (citizens of Botswana) greatly valued their arts, the introduction of 'modern' education overlooked its importance. This resulted in teachers treating it as a subject for the low achievers. As a result, teachers have not been committed to teaching art, craft and design as a subject in which there is valuable knowledge, understanding and skills to be acquired. There was no syllabus to guide teachers on what to teach. The Report of the National Commission on Education (RNCE, 1993) then saw the need to make the curriculum more practical and suggested that immediate initiatives should be taken to develop the art, craft and design syllabi.

Responding to this report, the Revised National Policy on Education (RNPE, 1994) recommended that "a wide range of practical subjects be included in the primary curriculum in order to help students develop an understanding and appreciation of technology, manipulative skills and familiarity with tools, equipment and materials" (Curriculum Development and Evaluation Division, 2002, p. 1). This resulted in the introduction of the Creative and Performing Arts (CAPA) programme for lower level (standard one to four) in 2002, which is comprised of four disciplines (art and craft, design and technology, music and physical education). The CAPA syllabus' main aims, are to help 
students develop creativity skills; problem solving aptitudes, critical thinking competencies, aesthetic recognition and appreciation, psychomotor dexterity along with positive attitudes towards practical work and productivity (Curriculum Development and Evaluation Department, 2002).

The importance of having a curriculum as a blueprint is very critical (Cleave and Sharp, 1986). These authors advise that primary school teachers need guidelines with supportive frameworks to help them develop confidence in their art, craft and design teaching. Cleave and Sharp (1986) explains that "the aim of such guidelines would be to contribute to curriculum cohesion, sequencing and continuity in the arts throughout the school" (p. 44). However, these guidelines could only achieve their goals if educators had sufficient knowledge, understanding and the skills to translate or implement the curricular in relation to the government policies. CAPA identifies specific objectives and practical activities in which students may be engaged to develop practical skills, and hence promote productivity. This contextual feature guided the exploration of how well primary school teachers engaged learners in practical activities. Little research has been conducted in relation to CAPA teaching. Research that has been reviewed revealed that most primary school teachers in Botswana have limited knowledge and skills in CAPA disciplines (Phuthego, 2006; Moalosi. and Molwane, 2008; and Mannathoko, 2009). Thus, having basic pedagogical knowledge in teaching, does not guarantee that teachers will successfully handle other disciplines.

\subsection{Purpose of the Study}

Art, craft and design (ACD) is one of the subjects that require active participation by learners to assist them in the development of creativity and practical skills. Thus, ACD is one of the subjects in which learners must be actively involved in hands-on-activities. This study, therefore, investigated the extent to which children were engaged in practical activities in art, craft and design lessons, that help them develop the basic practical skills suggested by the Botswana Lower Primary Creative and Performing Arts syllabus (2002). It further examined how far and how well theory learnt in $\mathrm{ACD}$ was interpreted through end-products creations.

\subsection{Research Questions}

Three research questions have been identified to help the focus of the study.

- To what extent do teachers engage pupils in practical activities?

- How far and how well do strategies used in the teaching of ACD, address the practical skills suggested by the CAPA syllabus?

- To what extent do practical ACD activities given to pupils and approaches used during instruction show evidence of developing their practical skills?

\section{Literature Review}

Art has served as a way of recording people's ways of life, for example; the culture of humankind and the first known examples include the rock art found on the walls of caves throughout Africa. Some of the best known examples of rock art in the world are in Southern Africa. Barnes (2002) viewed art, craft and design as effective components of communication that provide information through teaching aids, posters, newspapers and magazines. Donald and Fisher (2002) concurred with Barnes (2002) by recognizing that artists, through the ages have used art, craft and design to express the cherished values and provide poignant statements about conditions in the nation and the world. Thus, artists frequently function as social critics and visionaries. Their artwork helps others learn to see what they had been unable to envision. Fox and Schirrmacher (2012) explained that we can put old ideas together in novel ways or create new ones, to offer new sources of insight and illumination, which affords and expand perspectives about the world and the human condition.

It is within this context that, teachers must prepare art; craft, and design activities which might help students develop necessary practical skills, and motivate them to respond to community issues through visual communications. The adage 'one picture is worth a thousand words' conveys and echoes the importance of this message. Many art, craft and design educationists argue that art, craft and design is a vital means of self-realization within the framework of education based on the assumption that personal experience may be transmitted and utilized. Children need to discover themselves; but they also need to find out how their main interests, obsessions, needs, and abilities relate to others and society in general. This understanding must come through experience, and is one of the major rationales of art and craft education to achieve this.

At lower primary, art, craft and design play a major role in developing children's manipulative dexterity and perceptual skills (Lindstrom, 2006). According to Pitri (2003) children need to be enabled, not only to have ideas about the world, but also to act in it. Work in art, craft and design can lead to the development of a range of qualities 
and skills with a wide application and value. Furthermore, Argro (2004) and Szekely (2005) noted that through continual response to sensory experiences, the child will increasingly become aware that relationships, differences and similarities are part of the world, and hence develop problem solving skills. All these skills may be developed in children by effectively engaging them in practical activities such as art, craft and design, a practical subject dealing with visual content. Hickman (2005) maintained that one of the rationales for art, craft and design education ought to be concerned with noticing. He suggested that "visual education must surely concern itself with drawing attention to the subtleties of the visual world, which includes the intriguing, the interesting, the arresting and the beautiful" (p.137-138).

Our experiences as educators revealed that there is an implicit expectation, that at the end of a subject instruction, learners will know, understand and/or be able to do something that they were unable to do prior to the lesson. Thus, Hardy (2006) and Hallam, Lee and Gupter (2006) believed that art, craft and design builds fine motor skills through manipulation of tools such as scissors and paint brushes. They explain that through manipulation of materials and tools, learners develop the finer muscles and hence improving coordination. For the success of this development, Danko-Mcghee (2006) advocated that teachers should be trained on how to construct environments and activities that keep motivation, experimentation and curiosity alive as well as how to facilitate children's natural learning processes.

Like the Botswana lower primary CAPA syllabus, the National Curriculum for England introduced in 1999 has a similar view regarding the importance of art, craft and design in the primary school curriculum. That national curriculum notes that "art and design stimulates creativity and imagination; ...provides visual, tactile and sensory experiences and a unique way of understanding and responding to the world" (National Curriculum for England, 1999, p. 14). However, Kalin and Kind (2006) expressed concern about untrained teachers in art, craft and design, who may hold specific views that under value pupils' creativity. For example, those teachers may tend to think of the teacher as sole expert and the act of teaching as entirely detailed planning in advance as opposedas a response to pupils' inquiries and interests. The aforementioned educationists also believe that some teachers may also maintain certain preconceived, even stereotypical notions about ACD teaching and learning and children. On this note, Steers (2006) argued that creative pupils need creative teachers with the confidence to take creative risks. With regard to Botswana art education, teachers may not have much confidence in this discipline as most of the elementary/primary teachers have very limited knowledge and skills in this area. The Ministry of Education in Botswana, that is responsible for sending both in-service and pre-service teachers to teacher training institutions send few art students specialists. The Ministry may not be valuing the discipline as it is excluded in the Primary School Leaving Examinations (PSLE). The PSLE is the final examination that is given at the end of seven years in primary/elementary for selection purposes to enter into secondary school (High School).

Steers noted that "if we want to promote and firmly establish creativity in the school curriculum then providing the proper opportunity, the right environment and motivation will be crucial" (p. 1). Art, craft and design discipline, needs purpose built facilities, ACD skilled and creative teachers and relevant media for learners to extensively explore their ideas and various techniques. Nevertheless, previous conceptions about the role of a teacher, what constitutes teaching, and how pupils learn are currently being redefined in educational literature. In addition, new; creative visions of what constitutes teaching are under continued exploration.

\section{Research Methodology}

The purpose of this study was to examine the extent to ACD theory was translated into practice in order to develop children's practical skills. The study was a qualitative case study that was carried out in four primary schools in the South-Central and Central-North regions in Botswana. Data was generated from first-hand observations of art, craft and design lessons in four lower primary classes (standard two and four) and semi-structured interviews with the observed class-teachers. Semi-structured interviews were chosen as they provide the researcher opportunity to probe more deeply in order to obtain in-depth information (Merriam and Simpson, 2000). The study involved one primary school in the South-Central region which represented the urban, and three schools in the Central- North, one representing sub-urban, one remote and one in one of the remotest areas in the country. The observed classes were videotaped and analyzed later. The video camera was used to supplement eye capturing observational records (notes). One of the advantages of a video recording method is that it offers a "relatively "unfiltered" record of all behaviors and transactions which occurred in front of the camera and a permanent, detailed record is provided" (Simpson and Tuson 1995, p. 52). The interviews were also audio-recorded and then transcribed. The use of multiple sources of data collection improved the trustworthiness (Ary, Jacobs and Sorenson, 2010). 
The observation and interview strategies were adopted and adapted where necessary from Parlett and Hamilton's 1972 model of 'illuminative evaluation' which takes account of the wider contexts in which educational programs function. This approach is still in use. The technique is used by various researchers from different areas of specialization. According to Draper (1999) the illuminative evaluation approach aims to uncover the important factors latent in a particular situation in use. It would therefore, have been naive to ignore the fact that an instructional system, when adopted, undergoes modifications that are highly significant when evaluating the teachers' lesson presentations. I recognized the fact innovatory curricula cannot be sensibly separated from the learning setting or milieu of which they become part. Therefore; teachers were expected to have different characteristics which included different styles of teaching, experience, personal or private goals and professional orientation. Pupils' individual perspectives and preoccupations in art and craft lessons were keenly recognized. Thus, acknowledging the diversity and complexity of teaching and the learning context was seen as an essential pre-requisite for a serious study of the art and craft curriculum under the CAPA programme.

Care and focused intention were paramount in analyzing and discussing the classroom observation data to recognize each teacher as an individual in a different specific environment, with unique individual needs and interests in contrast to other interested parties. Judgment could not be made as to comparative teaching performance according to a set standard. Each learning community or classroom has its own dynamic, and teachers need to select practices that they believe are most beneficial for each group of students (Milbrandt, Felts, Richards, and Abghari, 2004, p. 24).

The guideline was designed to help collect relevant data emerging from the research questions, and hence sharpen the focus of what may be observed and questioned within the time-scale of the research programme. Although the study adopted an 'illuminative evaluation' approach, I could not ignore what led to the study and concentrate only on what teachers could manage. Other aspects which art, craft and design educationists could question or challenge, such as the relevancy of art, craft and design activities to the syllabus topics and objectives were also vital to the study. Thus, individual independent case studies were conducted to provide accurate accounts of what transpired in each of the classes. A general view of the teachers' interpretation of the art, craft and design curriculum at lower primary in four case study schools is presented by discussing the findings from all the classroom observations in relation to the interview responses and the CAPA Curriculum requirements from Botswana. For example, the CAPA curriculum has stipulated the aims, objectives and practical skills pupils should acquire. A specific example includes the development of skills in a range of practical processes to produce useful products, creativity, problem solving and self-reliant spirit. The main focus of the study was the evaluation of those curriculum requirements in particular, ACD practical activities.

The themes under observation and interview instruments were designed to focus on the application and outcomes of the teachers' capabilities in engaging pupils in practical activities and monitoring students' practical progress during lessons. Education documents such as the Education Policy, the Primary School National Curriculum, Botswana National Principles and Vision 2016 were considered in the discussion, as it is procedural for all the departments in the country to adhere to the government policies when developing an operation document within its system.

\section{Findings and Discussions}

It is important to share with the readers that art, craft and design education is a newly introduced discipline in Botswana curriculum. Lower primary curriculum was implemented in 2002 and introduced to upper primary level 2005. A limited number of teachers have been trained in this area. None of the four case study teachers observed during the study, specialized in the art, craft and design discipline. However, two did confirm that they studied the subject as non-specialists during diploma training. An effort was made to identify those who could have specialized in art, craft and design in each case study school so as to have representatives, but to no avail.

\subsection{Classroom observation findings}

Quite distinctive practical activities were employed in different case study classes. The main findings of the observation sessions were that teachers did not actively involve learners in the practical activities. Teachers explained the concepts orally but did not encourage pupils to apply theory during practical activities. For example, the teachers seemed to interpret the art elements as important during the oral discussion; however, they did not encourage their pupils to apply them during practical work. Teachers seemed to put more emphasis on concepts of the topics, and omitted the techniques and processes of creating products which could develop pupils' art, craft and design practical skills advocated by many ACD educationists such as Mannathoko (2009) and Hickman (2005).

Two teachers seemed to assume that pupils, if left to their own devices, develop artistically without the need for adult intervention. This influenced their lack of engagement with their pupils during activities. However, this needs to be 
re-evaluated, as suggested by ACD educationists such as Prentice (1995) who advocate for balance between freedom and control, as the greatest of the teachers' professional responsibilities. Those case study teachers who talked to pupils during their practical activities referred to materials and checked whether or not learners had finished without any guidance. The teachers seemed to focus on the finished products rather than support learning during the creative process. Findings from each level observed are discussed below:

\subsubsection{Standard Four Classroom Observation}

Two standard four teachers who were observed were both teaching the topic 'drawing'. The specific objectives from the syllabus required students to:

- draw the structure and composition of natural and man-made objects.

- $\quad$ observe and draw linear arrangements of natural and made-made forms.

- $\quad$ create light and dark effects in a composition.

- draw compositions from observation, memory and imagination.

- $\quad$ interpret a given theme.

The two standard four teachers both started their lessons by discussing art elements prior to engaging in the drawing activities. Examples of content discussed during oral lesson presentations included: Art elements (lines, shape, texture, color, form, space, tone or value). Pupils were asked to list art elements and their responses included: lines, shapes, colors and textures. They were later asked to state types of each of the art elements listed. However, the teachers did not encourage pupils to observe those elements while drawing. One of the teachers engaged his pupils in group work activity. An observation revealed that only one learner was drawing, while others were watching and others were playing. The drawing techniques were not emphasized when pupils were engaged in the practical drawing activities in order to promote their development of the drawing skills. There was no verbal guidance or review of the recently shared knowledge as students practiced the new skill. When pupils were given the drawing activity, the emphasis of the instruction was on natural and man-made objects. The teachers repeatedly told pupils to either draw natural or man-made objects.

After completing the end-products, pupils from both classes were asked to present their work to the classmates. The teacher set the criteria for presentations as follows: to state the materials pupils used to create products, the product they created and the types of drawing they made (whether they were natural or man-made type). Although they are the guidelines to art creation, there was no emphasis on how art elements were used to create products. Many ACD educators such as Barret (1979) and Ragans (2000) argue that line, shape, colour, tone, space and texture are elements which comprise our experience of the visual-tactile world. "It is through our awareness of these elements that we realize the potential of materials and the forms through which ideas are expressed" (Barret, 1979, p. 49). Thus, it is advisable to encourage pupils to apply those elements when creating, analyzing or critiquing artwork.

In teaching ACD, art educationists are concerned with the acquisition of practical skills such as drawing, pattern making and collage making. They are also concerned with the development of understanding and the acquisition of subject-related knowledge. However, Hickman (2005) suggest that "skill acquisition should be our priority in the first years of schooling up until the age of fourteen, with the focus for teaching being on threshold skills" (p. 36). He argues that as children progress in their skills and knowledge of ACD, the development of understanding becomes more important. It is vital for teachers, therefore, to consider Barret (1979) and Hickman's (2005) advice so as to motivate and provide children with the relevant guidance on practical work and hence promote their practical skills in various ACD topics. However, this may only be possible if teachers have adequate knowledge and skills in art, craft and design discipline. The next section discusses data collected through lesson-observation in standard two classes.

\subsubsection{Standard Two Classroom-Observation Findings}

The standard two case study teachers also showed limited practical skills in ACD subject. This led to the lack of assistance in guiding pupils in the process of their practical activities. Unlike the standard fours who taught the same topic, these particular standard two case study teachers taught different topics. One was teaching collage construction while the other was teaching patternmaking. In a collage lesson, pupils were required to use natural and waste materials to create collages such as; the use of cut-outs to construct a collage. The teacher emphasized materials to use when creating collages without any reference to the process or techniques of making a collage. Pupils were just told to collect materials and paste them without introducing the key concepts of collage making such as, 'sticking', 'overlapping', 'arrange' and're-arranging' objects before final pasting. This resulted in the creation of lower quality 
work. Some of the objects fell off; some spaces were left uncovered; and some of the areas were shaded instead of displaying pasted objects.

As pupils worked on their activities, there was no assistance given by the teacher as she moved around except asking pupils if the projects were completed. The remaining teacher who taught 'Pattern making' to standard twos misinterpreted the objective which required pupils to 'identify patterns found in the natural and man-made environment and create patterns with repeated lines'. She interpreted it to mean that natural and man-made patterns were the two types of patterns. However, the types of patterns are actually regular/planned, random and alternating. These concepts were never introduced or emphasized during practical activities. Art elements were also discussed theoretically, but never emphasized to be observed and applied when creating patterns. The concept of repeating certain art elements to create patterns was supposed to be the 'key' word for the lesson; however, this key concept, it seemed, was not grasped by most of the pupils. This was evident because pupils made images of combined shapes and colors without any' rhythm' as a design principle to consider when creating patterns or any artwork.

\subsection{Interview Data from Class-Teachers}

The first question sought to find out from teachers, how often they engaged their pupils in ACD practical activities. Responses included: When the objective dictates for practical, I rarely give practical work because it's a waste of time as I don't know how to teach and assess the subject, It depends, if I have time, I give them regularly, although, I have difficulties in assisting and grading artwork. Teachers were further asked what they expected from pupils when they create products in ACD. The extracts from the responses included: I want them to create objects as they are; honestly, I just tell them to do something because I don't have skills of telling them what to expect, I just tell them to draw or paint, depending on the topic, I want them to create objects as required by the objectives, but I have limited skills to really tell them what to do. A follow-up question was posed, to find out how they usually assist pupils with difficulties in practical work. All the teachers explained that they did not know what to say to pupils as they had limited knowledge and skills in the ACD area. These are some of their responses: I don't know what to say because I don't know anything about art; I have not done art before, therefore leave children to work on their own as I don't have knowledge in art; some pupils are better than me in practical work therefore, I don't want to mislead them. When asked where they got assistance for ACD work when they had difficulties, all the teachers concurred that they did not seek for any help since the subject was not taken serious in their schools. The results therefore, reveal that as pupils were working on their practical activities, teachers did not become directly involved or guide them on what they were doing and enhancing the learning process during the practical activities.

Barnes (2002) argued that children should be motivated to promote their development of skills by teachers creating an environment conducive to their learning, such as making materials available and discussing the work with them. He encourages teachers to teach pupils how to see the objects they are drawing in order to develop their drawing skills. On the other hand, Robinson (1982) is concerned that the teacher's role in ACD is complicated, as the task is not simply to let anything happen in the name of self-expression or creativity or to impose rigid structures of ideas and methods upon the young learners. He maintains that the need is for a difficult balance of freedom and authority. Coles (1992) concurs with Robinson (1982) stating that "one of the most difficult problems that teachers have to resolve is concerned with the balance between the pupils' freedom to explore and respond to experiences and the need to develop the appropriate learning skills" (p. 13). More confusion comes when the teacher has limited knowledge and skill in ACD as there may be no guidance on how pupils should apply the art elements when creating at elements and hence no motivation on art appreciation procedures.

\section{Conclusions and Recommendations}

It was established that, although all the case study teachers minimally engaged pupils in practical activities, the engagement was not effectively supportive because pupils were not guided on what to do. As a result, learners were deprived of the necessary practical skills which could benefit them economically after they complete their studies. There was insufficient preparation of teachers, especially in the practical aspect, which led teachers to have difficulties in helping pupils apply what was learned in theory. Thus, the students did not put the theory into practical use. One could question whether pupils had attained the targets stipulated in the lower primary CAPA programme which were designed to address the basic programme aimed at equipping students with basic skills for survival. As aforementioned, lack of emphasis on the techniques and processes of creating ACD work could have deprived pupils of some, if not most of, the necessary skills. The study, therefore, identifies the need to encourage teachers to opt for art, craft and design education when sent for in-service training in teacher training institutions. This would help them gain knowledge and understanding of the subject and discover various effective approaches and methods of teaching art, craft and design as a discipline. The study further suggests that the Ministry of Education and individual schools 
should identify specialists in ACD area and involve them in the teaching and learning of the subject. These experts could go further and provide teachers and pupils the necessary workshops in this discipline, building teachers' confidence in ACD teaching. The result would benefit pupils by helping them develop creatively. Workshop facilitators would include stake holders such as training institutions and practicing artists. Initiating these artistic professionals would enhance teacher education in ACD, resulting in the artistic support of the children of Botswana.

\section{References}

Argiro, C. (2004). Teaching with public art. Art Education, 57(4), 25-32. http://www.jstor.org/stable/3194122

Ary, D., Jacobs, L.C. \& Sorenson, C. (Ed.). (2010). Introduction to research in education. Belmont: Wadsworth Cengage Learning.

Barnes, R. (2002). Teaching art to young children 4-9. London: Routledge Falmer.

Barrett, M. (1979). Art Education: A strategy for course design. London: Heinemann Educational Books.

Botswana Government, (1993). The Report of the Commission on Education. Gaborone: Government Printers.

Botswana Government, (1994). The Revised National Policy on Education. Gaborone: Government Printers.

Botswana Vision 2016 Council, (2004). Vision 2016 - Long term vision for Botswana: Towards prosperity for all. Gaborone: Government Printer.

The National Curriculum for England (1999.). Art and Design Key Stages 1-3. London: Qualification and Curriculum Authority.

Chanda, J. (1993). African arts and culture. Massachutts: Davis Publications.

Cleave, S., \& Sharp, C. (1986). The arts: A preparation to teach. London: NFER.

Coles, P. (1992). Further guidelines for art education: Learning through evaluation and assessment, critical studies, Visual Language and Design. London: Hampshire County Council.

Curriculum Development and Evaluation Department (2002). Lower primary school syllabus, standard one to four. Gaborone: Ministry of Education.

Danko-Mcghee. K. (2006). Nurturing aesthetics in young children: Developmentally appropriate art viewing experiences. Art Education , 59 (3), 20-24, 33-35.

Donald, N., \& Fisher, D. (2002). Developing arts - Loving readers: Ten top questions teachers are asking about integrated arts education. [Online] Available: www.Eric.ed.gov, 6, May, 2013.

Draper, S. (1999). Observing, measuring, or evaluating courseware. [Online] Available: http://www.gla.ca.uk, 6, May, 2013).

Fox, J.E. \& Schirrmacher, R. (Ed.). (2012). Art and creative development for young children. New York: Wadsworth Cengage Learning.

Hardy, T. (2007). Domain poisoning: The redundancy of current models of assessment through art. The International Journal of Art and Design Education. 25 (3), 268 - 274. http://dx.doi.org/10.1111/j.1476-8070.2006.00493.x

Hallam, J., Lee, H., \& Gupta, D. (2006). An analysis of the presentation of art in the British primary school curriculum and its implications for teaching. Journal of Art and Design Education, 22 (2) 195-207. http://dx.doi.org/10.1111/j.1476-8070.2007.00530.x

Hickman, R. (2005). Why we make art and why it is taught. Bristol: Intellect Ltd.

Kalin, N., \& Kind, S. (2006). Invitations to understanding: Exploration in the teaching of arts to children. The Journal of the National Art, 59 (3), 36 - 41. [Online] Available: http://www.NAEA-Reston.org

Lindstrom, L. (2007). Creativity: What is it? Can you assess it? Can it be taught? The International Journal of Aesthetic Education, 22(1),143-55. http://dx.doi.org/10.1111/j.1476-8070.2006.00468.x

Mannathoko, M.C. (2009). Interpreting the new lower primary art and craft component of the Creative and Performing Arts, the Botswana National Curriculum. Case studies of four primary schools in the South Central and Central North Regions. An illuminative evaluation. Cardiff: UWIC.

Merriam, S., \& Simpson, E. (2000). A guide to Research for educators and trainers of adults. Malabar: Krieger Publishing Company. 
Milbrandt, M.K., Felts, J., Richards, B., \& Abghari, N. (2004). Teaching-to-learn: A constructivist approach to shared responsibility, The Journal of the National Art Education Association, 57 (5), 19-24. [Online] Available: http://www.NAEA-Reston.org

Moalosi, R., \& Molwane, O.B. (2008). Challenges facing teachers in the teaching of Design and Technology Education in Botswana's Primary Schools. Design and Technology Education, An International Journal, 13 (3), 27-30.

Parlett, M., \& Hamilton, D. (1972). Evaluation as illumination: A new approach to the study of innovatory programmes. Scotland: University of Edinburgh.

Pitri, E. (2003). Conceptual problem solving during artistic representation. Art Education, 56 (4), 19 - 23.

Phuthego, M. (2007). An Evaluation of the Indigenous Musical Arts in the Creative and Performing Arts Syllabus and the Implementation thereof in the Primary Schools Curriculum in Botswana. Unpublished DMusic Thesis. Pretoria: University of Pretoria.

Prentice, R. (2002). 'Preparing primary teachers to teach art and design effectively.' Journal of Art and Design Education, 21 (1), 72-81. http://dx.doi.org/10.1111/1468-5949.00298

Ragans, R. (Ed.). (2000). Art Talk. Ohio: MacGraw-Hill Publishing Company.

Robinson, K. (1982). The arts in schools: Principles, practice and provision. London: Calouste Gulbenkian Foundation.

Simpson, M., \& Tuson, J. (1995). Using observation in small scale research. Glasgow: GNP Booth.

Steers, J. (2006). Motivation, creativity, opportunity: Kent Visual Arts Conference, Maidstone, $5^{\text {th }}$ July 2006. [Online] Available: www.springerlink.com/index/m023754114223gh0.pdf (Retrieved 7 May, 2013).

Szekely, G. (2005). Teaching students to become independent artists. Art Education, 58 (1), $41-51$. 